Historic, Archive Document

Do not assume content reflects current scientific knowledge, policies, or practices. 



\section{3 \\ THIRTY-THIRD ANNUAL WHOLESALE PRICE LIST \\ $-\mathrm{OH}-$ \\ Trees,

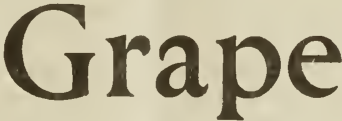 \\ Vines \\ Grape \\ SMALL FRUIT PLANTS, \\ GROWN AND FOR SALE BY \\ JOHN F. DAYTON,}

WAUKON, ALLAMAKEE COUNTY, IOWA.

Plants from this list will be packed in the best manner and delivered to forwarders without any extra charge therefor, after which they are at the risk of the purchaser.

Any order amounting to TEN DOLLARS may be filled from this list at the lowest rate quoted regardless of the number of each kind desired, but in smaller orders 50 plants of one variety will be furnished at hundred rates, and 500 of one kind at thousand rates. No order filled for less than one dollar. Remit by registered letter, draft, money or express order, payable at Waukon, Iowa. Terms are invariably cash with order. No credit given and no agents employed.

DO NOT send PERSONAL CHECKS. I have to discount them.

CERTIFICATE OF INSPECTION.

Each shipment of plants by me will be accompanied by a certificate from the State Entomologist that the stock is free from insect pests and disease.

\section{APPLE TREES.}

I do not grow a great number of varieties of apples, offering only those which by extensive trial have proven'adapted to the Northwest. Don't fool away your money on a high priced novelty. The first hard W'inter will destroy it. The Government and the State maintain Experiment Stations at public expense; let them decide upon the value of new iritroductions.

\section{SUMMER APPLES.}

TETOFSKY-One of the most hardy Russian apples. Tree an upright, rather slow grower; comes early into bearing and produces annually. Flesh juicy, sprightly acid, fragrant and agreeable; July and August.

DUCHESS-This variety is the one most extensively grown through. out the Northwest. It is vigorous, always healthy and hardy, an early and continuous bearer of large yellow apples marked with red, quite acid, but juicy and of good eating and cooking qualities. Season September and October. 


\section{FALL VARIETIES.}

PATTEN'S GREENING-An ivple orisinating in Northeastern Iowa, which has proven berd, and purustivo turughout Mibnesota and the Lahotas. Il has the aburavil or an we slate Horticuliural societies of

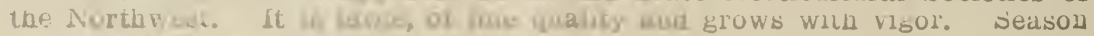
votover to Duceniber.

WEALTHY -1 Lis apple bes kecn widely grown and tried. It succeeds wherever amples cuu ue grown. It is vigorous and productive of besutiful iruit ol fiat qualits. If picked with care and piopersy stored it wall beey until teoriary, thougi ordinalily its season is Irom October to Necember.

HInEnvAL-Large, red striped, very sour, septemuer and October. kixtremely hardy, vasuabl as a stock for top-working.

FAIVIEUSt. (SLow Apple)-liedium size, roundish; crımson, sometimes striped in Northeri localicies. Hlesh snowy white; very teuder, tue, juicy, mud, sul-dcid; one of ne tinest dessert fruits. Hardy and puolitic. Very popular. Uclober and Decencber.

Beteres:

\section{WINTEK SURTS.}

GANO-Fruit is bright red on yellow ground, with no stripes; large, oblong, surtace smooth, polished; dots minute; Nasin shallow, sometimes deep; eye large, cavity deep, brown in color; stem meaium to long; core medium. Iree healby, vigorous and proutic bearer. January to April.

BEN DAVIS-Large, smoob, nedry covered with red; sub-acid, one of. the Dest warket sorts. Iree vigorous and healthy and wile not. the harriest, it rarely evor dies la dent co the pranter. Bear's young and is very pro 1 uic. A long keeper.

NORTHWESTERI GRELNING-1his is the hardiest Winter apple wath which 1 alu diciodutud. If Las wllistood all vicissitules of cold since its incroductiom, aoes not olishl, is vigorous and produclive of large frut of̈ excentent qually, hicu will falr treatment, will keep all Winter.

WOLF RIVER-flis apyle oldginated la Wiscomsin, and has been largeiy and piomauj giowi thoublout the dvortawest. It is very hardy aud vigorous. 1 he largest alid Losi showy fruit at cne St. Louis Expositicn was of this varety- Season December to January.

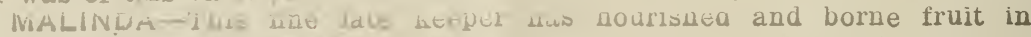
Ninnesota and Nortuerto lowi tor more tnan twenty years, and has proven

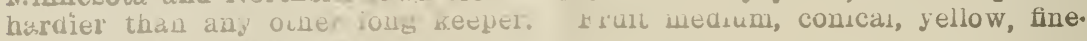
grained and neally sweet.

IOWA BLUSH-Meanm or swal, roundish, gleenisi-yellow with red biush, mild and very goou. December to duarch. valuavie for home use; very haray and pioductive.

SALOivit-Larse, rouud, yellow and red, mild and good. December to Apiil. Yearly aul annual bearer. Lree a scrous giower and hardy.

WALBRILGE- Ladium size; Dandsome, liaie łellow, striped with red; crisp, a late leeper; tree vers visolous, extremely hardy. Jauuary to May.

\section{CRAB APPLES.}

TRANSCENDENT-'Iree imwensely proauctive, bearing early. Fruit from one aud a half to two mcles in didmeter. Skin yellow, suriped with red. September to Octobes:

WHITNEY-This is a: large as some varieties of apples, very fine growing tree, extremely productive, quality test. Season september.

BRIAR'S SWEET-Ihere is 'Ic entirely hardy sweet apple, but by growing a variety of weet crab one can get an abundance of sweet fruit for pickling or preservalg. Tree vigorous, fruit large, of rich quality. wiptember. 


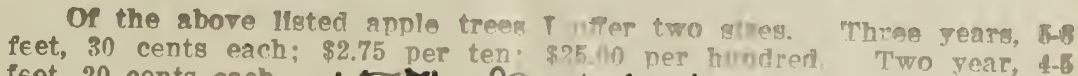

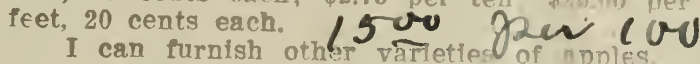
desired.

\section{CHFRRY AND DITTM TTRFES.}

EARLY RICHMGND CHERRY - Thls old anl Parorite varlets bears heavily, beginning when the tree is voing and small Fine trees 4 to 5 feet. 25 cents each. $\$ 9.75$ ner domen

LARGE MONTM!ORFNCY CHFRPY_Tres Tart hirdy and an immenge bearer: commences to fruit whtle roming Fritl remy larre. Fine flavor, and of hrioht clear. shining red. valiahle olwrm hers. a week later than Early Richmind. Fine trees. 4 to 5 fent 26 corls ogen. 8275 ner dozen.

DE SOTO PLUM-This nirm, which nirletraten st Te Sotn Wisconsin, about twentr miles from this nlare is the tepalino nium thronehont the Enited States. It is not surnassed for hardinges mulity and nroductiveness. Its onlv fanlt is that it oterhears and the pront should be thinned when too ahrndant, to maintain its nowal size

WOLF PLUM-This nlum is a freestane lurape than the De Soto. darker in color. and later in sezson than thet varlevis Tt is a verv viour ous grower. and hears heavily of prit which alwavs sells well. dozen.

Price for either varlety of nlum, 4-5 feet, 25 cents each; $\$ 2.75$ per

\section{CURRANTS,}

Two Year

FAY'S PROLIFIC-The lareest irulted variety, bunches

per doz. per 100

long, productive, quality good. nlants of moderate

growth, requiring good soll; a verv nomilar kind.....\$ $100 \$ 800$

VICTORIA-An erect eTower, large hroht red bunches very long, late, productive, valuahle. This mrrant nrolongs the season fully two weeks, and is the most vigor-

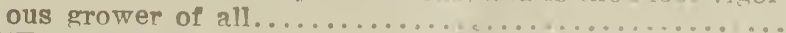

WHITE GRAPE-This is the crirtant nf all others that $100 \quad 600$ should be in the family garden, not only for its hendsome appearance, but its fine qualiter. Tto bunches are extremely long. herries large of a heantifil trang. lucent white and excellent flavor. The largest and decidedly the best write variet. $\ldots . . . \ldots \ldots \ldots \ldots . .100$

\section{GOOSFRFRRIES.}

HOUGHTON-Of American origln Wnst Feorols and productive. Requires rich soll and good leediag. Hardy and succeds evervwhere................ 125

$$
\text { GRAPE VINES, }
$$

The varieties I list are not ment in niminer, hit comprise the best, aud will please those who wish frutt rather thon fruitiesg experiments.

Two Year

WYOMING RED-A red grape of large glze, handisme per doz. per 100 clusters and fine apnearance, of shnerior qualitw nud ripens early. A good grower, productite nal a vary promising varletv. Thie best red gtrne .............

CONCORD-Well known everywhere and ous of the mont reliable grapes. 
NIAGARA-The great white grape, the most valuable of its kind introduced. Bunches large and compact, color pale green at flrst, changing to pale yellow when fully

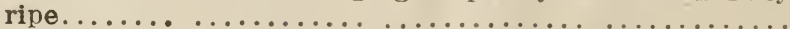

WORDEN-An Improved Concord, being larger in both bunch and berry, handsome, nearly two weeks earlier and of better quality. As it is difficult to propagate, mány vines of Concord are sold for it.............

\section{RED RASPBERRY PLANTS.}

MILLER-Bright red color, which holds after picking, bringing the highest market rates. Stout, healthy, vigorous grower. Berries large, hold their size to end of the season; round, core small, do not crumble; the best shipper; rich fruity flavor. Commences to ripen with the earliest; is very productive and of ironclad hardiness............................................

CUTHBERT-A strong grower, productive, fruit large,
red, flne quality, season medium till very late; good for market or home use. A standard and valuable

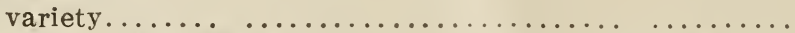

TURNER-This is the hardiest variety, a strong grower free from any ailments, always on hand with a crop of fruit of the best quality, fine bright color, long season of fruiting, a favorite everywhere............... 100

\section{BLACK VARIETIES.=sTip Plants.}

Black raspberry tip plants should go by express.

CUMBERLAND-The largest of all Black-caps. A healthy, vigorous grower, throwing up stout, stocky, wellbranched canes that produce immense crops of magnificent berries. Fruit very large, firm, keeps and ships as well as any of the blacks-the most profitable market variety......................... 150

HILBORN-Early in ripening. Fruit jet black, nearly as large as Gregg and better flavor, a strong grower, perfectly hardy, few thorns and very productive. Very showy and brings highest price in market............

\section{BLACKBERRIES.}

SNYDER-Extremely hardy, enormously productive, medium size; no hard, sour core; sweet and juicy. The leading variety when hardiness is the consideration. Early......................................................

TAYLOR-Berries of fine flavor, larger than Snyder. Canes
of vigorous growth, ironclad hardiness and wonderfully prolific. Ripens late, fine companion for Snyder

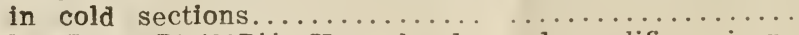

WESTERN TRIUMPH-Very hardy and prolific, ripens early. Fruit of medium size, good quality. It is largely grown in Canada, where a hardy variety is re-

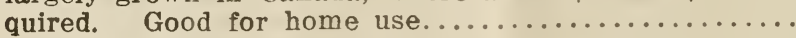


ners removed and roots straightened, so that they weigh much less than the plants that are usually sold, making a great saving in expressage, and they are much easier to plant.

I test the new varieties and list only those I think of actual value. Most new kinds are worthless for general cultivation. Those I recomnıend do well without petting.

If plants are desired wy mail 25 cents per 100 must be added to the price given to cover postage. No plants by mail at 1,000 rates.

The varieties marked " $\mathrm{P}$ " are pistillate, and REQUIRE TO BE FERTILIZED, by having some perfect flowering variety planted in every third row. All varieties not so marked are perfect in blossom and may be planted alone.

All plants sent out by me are grown in new beds which have never been weakened by fruiting, but are grown for plants only.

Only well rooted plants are sent out, all old or imperfect plants being excluded. Strawberry plants should go by express.

BEDER WOOD-This is a very desirable early berry for either home or near market. Its blossom is perfect. The berry is round, or regular form, bright scarlet, and of good quality. A great bearer..............

BRANDYWINE-The plant is remarkable vigorous, healthy and prolific, berries very large, heart shape, firm, a good shipper, colors evenly. Begins to ripen in mid-

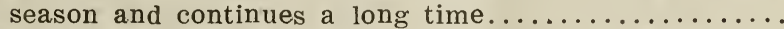

CRESCENT (P) -Valuable by reason of its succeeding with but little care and even under neglect. Excessively productive, a vigorous, slender grower, matting the ground closely with runners, which for the best results should be thinned out. Berries are medium in size, attractive scarlet, of fair quality. For a local market it is a very profitable sort to grow. Early..........

LOVETT-Plant vigorous, healthy and productive, ripens first, fruits very early and continues a long time; fruit large, very firm, good shipper, bright crimson color and a very fine flavor; an excellent pollenizer, valuable in

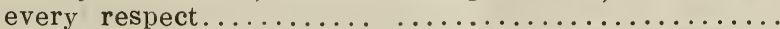

PARSON'S BEAUTY-A good healthy grower and immense cropper of large solid berries of good form, color and quality. There is probably not a variety in existence that will outyield it, or one that is more reliable.....

PHILLIPS - A new variety which yields heavily. Berries uniform in size, large and of excellent quality. Sea-

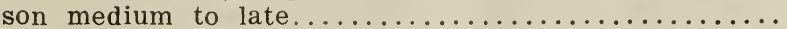

SAMPLE (P) - It is of large size, quite firm, commences to ripen mid-season and continues to very late, keeping up a continual supply of large berries to the end. The foliage is large and healthy, fruit of good quality......

SEAFORD (P)-One of the largest fruited varieties; a strong grower and productive; of excellent quality and

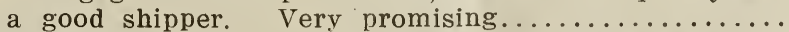

SUTHERLAND (P) -Very vigorous; an abundant bearer of finely colored and flavored fruit. Good for canning

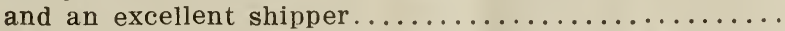

SENATOR DUNLAP - No variety has been more thoroughly tested in all sections of the country during the past five seasons than this. The plants are not large, but deep rooted, bright glossy green, without a sign of disease and will grow anywhere, and with most any 
kind of treatment. It is rery productive and nsually matures every herry, and they are of medium to large, regular size and shape, bright glossy red, a good ship-

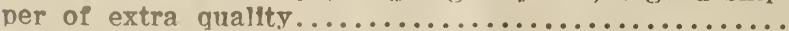

WARFIELD (P)-Succeeds everywhere and has become one of the leading market berries. It is of good size, excellent flavor. dark red color, firm. one of the very best shinpers, commands the best prices in the market. Vigorous grower, nerfectlv healthy, ripens after Crescent, extremely productive...................

\section{SPECIAL OFFERS.}

For ONE DOT, TAR $T$ will furnish 250 strawberry plants in three varieties. YOTTR SET ECTTON from the above list.

For $\mathrm{NNE}$ DOLLAR $I$ will send 175 strawberry plants, 3 varietles, $B Y$ MAIL, PREPAID .

\section{HYBRID PERPETUAL ROSES.}

The Hvhrid Perpetuals are among the most valuable of all Roses for cold climates, being hardv. The oflwers of this class are very double and of immense size, delightfully fragrant, and of the most gorgeous colors, but no shade of vellow. The plant is strong. vigorous rower, requiring but little attentinn, though protection in the Winter in exposed places is necessary. They are much improved in size and beauty by good cultivation and rich soll.

The Roses which I offer are large, two-vear, fleld grown plants. You can't buy them elsewhere for twice the price I ask. Prices of all Roses 25 cents each. $\$ 2.50$ per dozen.

PAUL NEYRON-Bright clear pink: extra large and double; free bloomer: vignrous.

MARGARET DICFiSON-White, with pale flesh colored center; a magniffcent rose.

PRINCE CAMILLE DE ROHAN-Very dark, rich velvety crimson, shaded black. The best dark rose.

GEN. JACQUEMINOT-EVerybody knows the "Jack" rose to be the standard hright colored perpetual.

CRIMSON RAMBLER CLIMBER-The nlant is vigorous, making shoots from elght to ten feet long in a season. The flowers are grown in great nvramidal panicles, each carrving thirtv to forty blooms; the individual flowers are one to one and one-half inches in diameter. and remain in perfect condition a lone time. The color is a bright, vivid crimson, show. ing none of the purnlish tint so common in crimson roses.

Do not nermit roses to dry out after planting. Keep moist until they show leaves.

\section{HARDY FLOWERING SHRUBS.}

TREE HONFYSUCKLE-TARTARICA-Pink flowers contrasting beautifully with the foliage; blooms in June.

Large fleld grown snecimens, 25 cents each.

LILAC-LARGE FIOWERING WHITE-A beautiful variety; has very large pure white nanicles of flowers.

PURPLE-The well known varietr, one of the best. A good grower; flowers and voune wood fragrant; purnle.

Large fleld grown snecimens of efther variety 25 cents each.

HYDRANGEA-PANICULATA GRANDIFLORA-The grandest as well as most popular of all shrubs. Unsurpassed for the lawn, as a hedge or for cemetery planting. It readly attains a height of 5 to 7 feet; hardy 
in all localities, needs no protection in winter; blooms every season in July and August and continues in bloo $\mathrm{n}$ for two or three months; the flower panicles are massive, cone-shaped, often measıring 10 inches in length, and hare a pleasing variation of color, changing from the original pure white to pink.

Large field grown plants 25 cents each.

SYRINGd-Of vigorous habit, very hardy, with large, handsome foliage. and beautiful white flowers, produced in the greatest profusion at the blossoming season. It merits a prominent place in all collections of shrubbery.

Large field grown specimens 25 cents each.

SNOWBALl-A well known favorite shrub, with globular pure white sterile flowers, the latter part of May. Each larger than a pure white snow bail. 'This is popular, and justly so, easily grown and attractive.

Price 25 cents for large field grown plants.

SPIREA VAN HOUTTE-The grandest of all the Spireas; it is a beautiful ornament for the lawn at any season, but when in flower it is a complete fountain of white bloom, the foliage hardly sho ving Strong 2 and 3 year old plants 2.5 cents each.

WEIGELIA ROSEA--One of the most conspicuous shrubs that we cultivate; flowers pink. It is admirably adapted to small lawns or gardens.

Large field grown plants 25 cents each.

CLENATIS PANICULATA-The finest vine grown, entirely hardy. growing from the root each season. Very vigorous when established, one vine will cover one hundred square feet of surface; foliage dark glossy reen, nerer blighting and insect proof. The vine is covered with white flowers in September. Strong vines 2.5 cents each, $\$ 2.50$ per dozen.

GLADIOLUS BULBS--If you wish lots of flowers in Summer, at small expense, plant Gladiolus. No insect pests trouble them. the bulbs are easily kept over Winter like potatoes and with little care of the offsets increase rapidly. The bulbs I offer are extra large. and will give much larger spikes and more abundant bloom than those ordinarily sold. Fine, named kinds. mixed, 2.s cents per dozen; $\$ 2.00$ per 100 .

\section{EVERGREENS.}

AMERICAN ARBOR VITAE, SCOTCH PINE, WHITE PINE, NORWAY SPRUCE-The above varities are those best adapted to culture in the Nurthwest. I offer transplanted trees of either kind, 12 to 18 inches, 15 cents each; 18 to 24 inches, 20 cents each; 2 to 3 feet, 30 cents rach.

I do not recommend Fall Planti:ig of any nursery stock, or of small fruits, as unless handled, and planted carefully, success cannot be expected. and $I$ do not issue any Fall list; yet if desired I will furnish any stock described in this list, at prices named, after October 15th.

If any mistakes occur, notice must be given within ten days after the arrival of plants.

I might fill volumes with testimonials which I have received praising the plants which I nave sold, but I prefer to let the plants which I send? speak for themselves, rather than make up a catalogue in that way.

In closing permit me to say that I have a large fruit farm. Growing as I do, fruit for market, I keep only those varieties that are productive, and grow them in great quantities. I do not issue an expensive catalogue, nor do I list high priced novelties of which ninety-nine in every hundred are worthless, but I furnish plants which are suitable for general cultivation and only those which are of first size and quality.

As to my financial standing, I refer to the Cirizens' State Bank, or First National Bank of Waukon, or to any commercial agency. I give no 

SPIREA VAN HOUTTE-The grandeat of all the Spireas; it is a beautiful ornament for the lawn at any sea.nn. but when in flower it is 2 complete fountain of white bloom, the fol dly showing. Strong 2 and 3 year old nlants " cent" "

WEIG'

cultivate

3. shrubs that we

Larg

CLE.

growing frus

vine will cover ob.

or gardens.

green, never blighting and twoun. The ... is covered with white Howers in September. Strong vines 25 cents each. $\$ 2.50$ per dozen.

GLADIOLUS BULBS-If you wish lots of flowers in Summer, at small expense, plant Gladiolus. No insect pests trouble them, the bulbs are easily kept over Winter like potatoes and with little care of the olifsets increase rapidly. The bulbs I offer are extra large, and will give much larger spikes and more abundant bloom than those ordinarily sold. Fine, named kinds, nixed, 25 cents per dozen; $\$ 2.00$ per 100.

\section{ERGREENS.}

WA)

OH $\quad$ AE, SCOTCH PINE, WHITE PINE, NOR-

the Nuri -Dove varieties are those best adapted to culture in 16 cents each; 18 to 24 inches, 20 cents each; 2 to 3 feet, 30 cents each.

I do not recommend Fall Planting of any nursery stock, or of smali Iruits, as unless handled, and planted carefully, success cannot be expected, and I do not issue any Fall list; yet if desired I will furnish any stock described in this list, at prices named, after Or $r 15$ th.

If any mistakes occur, notice must be giver ten days after the arrival of plants.

I might fill volui the plants which I h: speak for themselves,

In closing permit.

as I do, fruit for mar?

and grow them in

logue, nor do I las os prs

ten days aiter the

hundred are worthless, hut I furmsu siants which are sutable for general cultivation, and only those which are of first size and quality.

As to my tinancial standing, I refer to the Citizens' State Bank, or First National Bank of Waukon, or to any commercial agency. I give no and beautiful white flowers, produced in the greatest profision at the blossoming season. It merits a prominent place in all collections of shrubbery.

Large field grown specimens 25 cents each.

SNOWBALL-A well known favorite shrub, with globular pure white

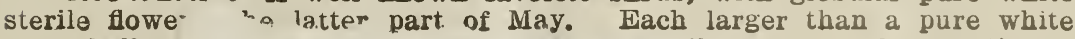
snow ball.

Price 25

in all localitiv

July and August is

Hower panicles

in length, and $h$ :

original pure white th - m casily grown and attractive.

ats W 1 send 1 that way.

uit farm. Growing w that are productive, uu ISsue an expensive cata- of which ninety-nine in every

Large field grown plas. \& .. 3i-m

SYRINGA-OI vigorous habit, very hardy, with large, handsome foliage, 
directions for cultivation in this list, but I furnish full instructions with each order. ORDER EARLY, as the rush during the season is great. Address all orders to

\author{
JOHN F. DAYTON, \\ Waukon, Allamakee County, Iowa.
}

\title{
POULTRY DEPARTMENT.
}

The greatest profits in business come from what are known as "intensive methods", by which everything is utilized.

The best farm combination which I know of, is the growing of fruit and poultry together. Before and after fruit ripening the chickens keep the worms and bugs from devouring the plants; they furnish the most valuable fertilizer, and large returns can be obtained from a small investment in land, plants, and eggs or fowls.

\section{BARRED PLYMOUTH ROCKS.}

The Barred Plymouth Rocks are to-day the most popular and best known variety of pure bred poultry in the world. They are without doubt the best general-purpose fowl. They are good layers, excellent for table purposes, and are very healthy and hardy.

I offer eggs from nine selected pens, all birds scored; containing Prize Winners at exhibits at Rockford and Rochelle, Illinois; Iowa State Shows; Cskaloosa and Ames, Iowa.

Either Pullet or Cockerel breeding at $\$ 1.00$ per 15 . Why pay five times as much for eggs from inferior birds?

\section{WHITE PLYMOUTH ROCKS.}

Excepting in plumage, the White Plymouth Rock is an exact counterpart of the Barred variety. As market fowls and for table purposes the White Plymouth Rocks stand the best. The chicks are very hardy and vigorous and mature young. I have one of the best flocks of White Ply. mouth Rocks in this country and am in a position to please the most exacting customer. The fowls that I am breeding from this season score as follows: Hens and pullets, 92 to 95 points; cocks and cockerels, from 92 to 95 points. Prize winners at Rochester and Dubuque.

7GGS-Per 15, $\$ 1.00$.

\section{SINGLE COMB WHITE LEGHORN}

Whenever hens are kept exclusively for eggs, the variety of fowls is always the single-comb White Leghorn, which is the great egg producer.

They are non-sitters, reat foragers, and one of the most beautiful of all fowls. My birds are large and pure white, and all reeding stock score high.

EGGS-Per 15, $\$ 1.00$.

I guarantee all eggs shipped by me to be true to name. I give my stock the expert care that insures fertile eggs. In case 8 in each 15 esgs do not hatch, I will duplicate the original order at one-half price (excepting when eggs are sold at reduced prices).

STOCK FOR SALE at all times. Write for what you want and I will quote a reasonable price.

JOHN F. DAYTON, Waukon, Iowa. 